\title{
Traditional African (the Igbo) Marriage Customs \& the Influence of the Western Culture: Marxist Approach
}

\author{
Aaron A. R. Nwabude \\ Nigerian Defense Academy: Africa’s Top Military University, Kaduna, Kaduna State, Nigeria \\ Email: aaronnwbd@gmail.com
}

How to cite this paper: Nwabude, A. A. R. (2022). Traditional African (the Igbo) Marriage Customs \& the Influence of the Western Culture: Marxist Approach. Open Journal of Social Sciences, 10, 224-239. https://doi.org/10.4236/jss.2022.102016

Received: December 9, 2021

Accepted: February 20, 2022

Published: February 23, 2022

Copyright ( 2022 by author(s) and Scientific Research Publishing Inc. This work is licensed under the Creative Commons Attribution International License (CC BY 4.0).

http://creativecommons.org/licenses/by/4.0/

\section{(c) (i) Open Access}

\begin{abstract}
The emergence of clusters of traditions and cultural civilization of the wider Igbo society and the influence of the Western culture necessitated the need to review the traditional Igbo marriage and customs. This study looks at the pre-existing traditions of marriage(s), its values, beliefs and practices in Igbo land and the influence of the Western Judo-Christian cultural and religiosity which was passed unto us by the introduction of Christianity, Church and Canonical Laws into African Soil. The researcher approached this paper in a rather different genre, portraying a "Marxist perspective". The study thus, assumes that a qualitative research paradigm and method of data collection are interviews, and online research. Findings reveal deep rooted cultural differences (traditional and alien), which resulted in marriage clashes due to sometimes conceptual beliefs amongst the Christians and non-Christians alike. One such difference includes; the right of individuals to contract marriage without the consent of their parents in the West, whereas in Igbo land and more so in African context, marriage is seen as a union of two different families. In that respect, individuals cannot enter the contract of marriage without the sole express permission of their parents. Consequently, doing so would invalidate the marriage to a mere friendship without any form of legitimacy. Finally, compulsion is adhered to the traditional Igbo marriage custom while this is not the case in the Western cultural traditions. Thus, in this study, the researcher pertinently recommends respect to each method and to give to Caesar that which belongs to him and to GOD that which belongs to GOD.
\end{abstract}

\section{Keywords}

Traditional Marriage, Cultural, Bride-Price, Marxist Perspective, Igbo, Christianity, Osu, Igboland, Umunna, Ndi-Chie, Western Society, 
Igba-Nkwu, Chi-Ukwu

\section{Introduction}

The emergence of clusters of traditions and cultural civilization of the wider Igbo society dominated the early centuries from 1408 to the present period. Throughout Africa, traditional or cultural marriages which provided the richness of natural continuity of life are fast fading out due to the influx of the alien Western culture. In Africa, especially in Igbo land, marriage is the only known and acceptable incubator for the raising of socially balanced and functional moral society (Children). Today that strong, socially acceptable core value of our culture and tradition of marriage as ordained by CHI-UKWU (the Almighty God) is gradually being eroded, thus giving way to the western styled church wedding. The reason is obvious, due principally, to the coming of the West, the influence of the Church, the appearance of the Christianity on many tribal lands of the Igbo and the Eurocentric missionaries; all of which have led to the disintegration of belief system within the Igbo society. The West have thus, deprived the Igbos' and the Africans in general, the reception and good nature of the customary marriage due to the so-called regular union arising from Sacramento's western styled church wedding (Atado, 1998).

As an example of method approach which examines the value of traditional marriage rights in Africa and the West (i.e., new world), this article would focus upon the Igbo land traditional marriage customs and what influence the invasion of the Western culture had on marriage value systems. The researcher approached this paper in a rather different genre, portraying a "Marxist perspective" for two reasons; firstly, the exposure of what was the archetypical system of the traditional and cultural values of the Igbos in its entirety as a result of the entrants of the Europeans into the traditional homeland of the Igbos. Secondly, Marxism provided the platform for critiquing marriage that was in existence prior, through the custom and tradition throughout the Igbo land, and then the influence of the West through the Church and Canonical laws. The researcher however, attempts to discuss the issues of traditional marriage in Igbo land and the influence of the Western culture as derived from interviews and online research by concentrating on the following headings and sub-headings.

\section{Background/Review of Related Literatures}

On a general note, the entrant of the Western culture into the traditional African cultures brought its own social and cultural norms in both the traditional, social and commercial scenes. According to Hastings' study on the mission of the Church in modern Africa, the present ecclesiastical instance on the observance of canonical form in Africa betrays the fundamental theology of marriage, namely, that the sacrament of matrimony is the sanctifying or the sanctification of a natural relationship, made effective by the people themselves and not by any 
sacred minister (Hastings, 1995). Culturally, there are enormous indispensable elements in Igbo marriage process, e.g., the payment of bride-price and the procurement of parental consent. The first step in the customary marriage process is always the initial encounter by both involving families, where the groom would visit the bride's immediate family. This visit is usually accompanied by the groom's father and where the father is disposed due to death or illness, the eldest member of the immediate family accompanies the groom. Culturally, this is only a visit and does not warrant any gift of item however, as goodwill, the groom and his family are free to go with kegs of palm wine, a bottle of hot drink (usually, a bottle of Schnapp) and kola nuts. So, on this day of appointment, the suitor's family would carry a keg of palm-wine, or a bottle of Schnapp, and cola nuts to the bride's family where intentions to marry their daughter is declared for the first time to the parents. The groom's father would introduce himself to the bride's parents, explaining the reason for their visit and officially announcing his son's interest in marrying their daughter. Following this declaration of interest, the bride's parents would then call out the bride-to-be to seek her knowledge of her suitor and to know whether she would want the suitor to marry her. What follows next will be determined by her response and if positive, the suitor and his father would be asked to proceed on the second phase which includes the investigations and discussion on the payment of bride-price. It is after this visit, that the bride's family would begin the process of investigation on the suitor's family. Likewise, the suitor's family would carry out their own investigation on the bride's family. This process of investigation starts immediately, following the suitor's family officially making initial appointment with the bride's family in order to declare their intention to marry their daughter. The importance of investigation cannot be overemphasised. The process which checks the background and history is thus, carried out in order to ensure that bride's family or the groom's family harbours no invisible hereditary disease, or are not once an "Osu" as is called in Iboland, otherwise called outcast in English language i.e., something dedicated to the idols, ostracised and as such becomes a taboo for the son of the soil or the free born to relate to or be associated with. The investigation further checks for divorce rate, fertility rate, infidelity and bad behaviours in both families, but more to the bride's family.

The progress of the next meeting will then be determined by the satisfaction by all parties especially the bride's family who is interested on whether the groom-to-be might be man enough to take care of their daughter as well as their children. The next phase is the coming together of the two extended families: the bride's extended family called "Umunna" and the groom's family who can be as much as 20 - 25 people accompanying him. The crucial thing about this meeting is the reaffirmation by the groom's family that they are really interested in marrying from the other family in the presence of both extended families. The bride's family gives their consent and the bride is also consulted who gives her final consent. When this is established, then the traditional wedding date will be fixed and the list of bride-price may be given to the groom's family. On this visit, 
traditional Igboland custom demands that the groom takes along with him some gift items, such as kola nuts, kegs of palm-wine, cartons of beer, crates of soft drinks, packets of cigarettes, snuff, tobacco and probably a goat. These items would be shared amongst the two families in merriment. Following this phase is the engagement, negotiation and payment of bride price known traditionally as "Ime ego" in Igboland. Culturally, this aspect (bride price) differs slightly amongst different parts of Igboland. Usually, the amount of money paid as bride price is relatively small, and can be as little as 20 - 40 Naira, part of which would be handed back to the groom by the bride's father. It is the extra gift items the groom shall provide later on that actually constitutes the larger part of the bride price.

The acceptance of bride-price signifies, not only the support of the marriage by the two parties, but also the involvement of both sets of parents in the settlement of bride-price. Bride price in Igbo culture (also in other African and Asian cultures) is the transfer of physical cash or money from the groom to the parents or the family of the bride at the time of marriage agreement which signifies the acquisition of the rights by the groom, of the bride's labour and reproductive ability (Anderson, 2007). Therefore, the parental consent, the involvement of the two families (the bride and groom's family) and the payment of bride-price is seen by all and sundry as the concrete foundation that cements the marriage right, provides legitimacy as well as fostering true and lasting marriage without which there was no marriage (Anderson, 2007). The significance of the above factors, and especially the bride price cannot be over emphasised in a true and complete Igbo (African) traditional marriage rights. They therefore, fundamentally, signify a complete and total actualisation and fulfilment of Igbo traditional heritage which must be done before the bride and groom are pronounced as husband and wife in accordance to the native law and custom (Emecheta, 2011; Alewo \& Olong, 2012). The bride-price or dowery consequently, is the only marital right which is generally accepted in all Igbo tradition to solidify marriage, without which there was no marriage. It is such a symbolic element of the marriage constructs that if peradventure, there are children, such children are not recognised by the groom's family, until bride price is paid. The bride-price therefore is a blood cleanser that removes shame and insults from the woman the moment she becomes legally married to her husband (i.e., after the bride price has been paid) in accordance to the tradition and culture, which again gives her honour and a sense of community value amongst her peers in her husband's home and his family (Eniola \& Aremo, 2020). It provides peace of mind and respect because she cannot ordinarily be driven out of her husband's home, unless on the unfortunate event of problem arising from the marriage which results in separation. In this situation, bride-price paid must be returned back to the groom's family before the woman begins to contemplate marrying another man. Finally, if the woman in question is in abusive relationship and opts to back out, she cannot easily leave the marriage unless the dowery is returned and accepted by the groom's family. If the husband refuses to accept the refund, and 
the woman goes ahead and marries another man, the children from this new marriage automatically and traditionally, belongs to the first husband because legally, the woman still belongs to the first husband irrespective of the children. Therefore, until the bride-price is accepted by the first husband and family, the woman is not due for another marriage. This could be likened to the English marriage divorce, where a woman cannot legally marry another man until she is fully divorced (Ryznar, 2010).

\subsection{Movement of People across Cultures}

This period (1408-2008) witnessed the emergence of cluster of traditions and cultural civilization across the wider society. For the Igbos, it was the dilution, enfeeblement or watering down of their traditional principles and cultural heritage. The very core values of the tradition of marriage as ordained by CHI-UKWU (the Almighty God), and binding on the people. However, certain forces may account for this; firstly, the economic downturn in some parts of the world, the growth and emergence of new world economy that has fuelled the trans-Sahara movement. Thus, the peoples' movement across cultures and the influence of education has enabled marriage of convenience amongst individuals in the global scene. Secondly, the business of what I call; the developing countries immense contribution to this philosophy of change. With this change in culture, came attitudinal change, power domination of different kinds, mass movement of people for employment opportunities and the eventual quest for settlement wherever the boat landed.

Following the above, the question of the closeness of people with different traditional beliefs and cultural orientation seems unavoidable. Consequentially, the problem of tolerance and acceptability therefore arose out of the mixture of social and cultural values that are separate and distinctive and which, in effect ran contrastingly with one and another in the perspective of the people. Furthermore, as a result of this closeness, the chances of cultural war as groups fail to recognise each other's cultural presence and deportment within the society becomes inevitable. It follows therefore, that the struggle for recognition and cultural supremacy thus far, may go beyond the traditional plea for tolerance, thereby conceding the validity of society's disapproval and relying on its self-restraint (Parekh, 2000). There is no doubt the fact that humans feel more at peace with those of their own. They seem to rebel against imported and dappled traditions and cultures coming from other members of the society which were alien to them, and in this case, the western cultures.

The entrant of the Western culture into the traditional African cultures brought its own social and cultural norms in both the traditional, social and commercial scenes. They brought a cultural paradigm that encompasses all socio-economic aspects of the African traditions and in particular the Igbo cultural tradition, with the attendant policies for individualised and commercialised expansionist nature within the culture of (marriage). It must be noted here that 
this customised cultural imbibe may work well in certain cultures and may not be so suitable in other cultures. Since Adam (i.e., since the beginning of first man), the general principle of cultural and religious acceptability has always posed an issue amongst people and society. This paper deliberately looks at the intractable differences between the two different cultures, i.e., the African and the Western Society and the way this has impacted on the society at large.

\subsection{The Concept of Bride-Price}

In Igbo traditional and cultural practices, the concept and practice of bride price (Emecheta, 2011) assume a seriously sensitive cultural issues, and where there was no bride-price paid culturally, marriage had not taken place. Although, the Igbo cultural practices have undergone some significant changes over the years, the concept of bride-price predates the arrival of the Western culture. Prior to independence in 1960, bride-price in Igbo land involves the settlement of marriages with items such as ornaments, cowries, bottles of schnapps, clothes, he-goats, fixed number of tubbers of yam, or kegs of palm-oil. At this time, cash was never in use and groom's parents provide the necessary economic support to their son. However, in today's Igbo traditional or cultural marriage, the emergence or the involvement of cash has become the practice and sometimes, outright negotiation of the amount to be paid is undertaken by both parents taking into cognisance the level of wealth of the groom and educational level of the bride. Usually, the bride's family determines the amount of money to be paid by the groom's family. The determinant factors differ from region to region and from town to town. In some parts of Igbo nation, the bride's parents provide a numbered bride-price list to be handed over to the groom upon request. Sometimes, this list is negotiated and pruned to accommodate the financial wealth and statues of the groom especially where the bride is not well educated. This article explores the traditional African (the Igbo) marriage culture and the influence of the western cultural practices.

\subsection{An Overview of Igbo Society}

Who are the Igbos? the Igbos are found in the Southern part of Nigeria. They are one of the three main tribes in Nigeria with population numbering over 60 million. The Igbo people have been quoted as having migrated from the Jewish kingdom (Bruder, 2008). They are the descendants of Eri, the fifth son of Gad, Gad being the seventh son of Jacob, and Jacob being one of the sons of Abraham as indicated in the book of Genesis (Genesis 46: 15-18, \& Numbers 26: 16-18). They are therefore referred to as the black Jews who traversed Sahara Desert from Egypt with some companions before the exodus of Israelites from Egypt (Oduah, 2013). Eri and his companions had travelled to the Southern parts of Nigeria through river-water where they then came to settle at the confluence of Ezu and Omambala rivers in in present-day Aguleri, Anambra State. The Igbos are one of the most influential tribes in Nigeria known for their resilience, busi- 
ness acumen and hardworking characteristics, intelligence, enterprising and entrepreneurial spirit.

The Igbo speaking people are one of the ethnic groups located in the south-eastern part of Nigeria with unique cultural and traditional heritage. Politically, every clan, village or town is an autonomous unit, and can determine its method of governance besides settling matters affecting it through meeting of their elders and title holders. The elders constitute a permanent body called Ndi-chie: the rulers and administrators of general affairs of the community, charged with legislative, executive and judicial functions in the society, for which they discharge without encumbrance. There is no separation of powers; those who make the laws also interpret and execute them by delegating for implementation. One may sometimes ask; does governance reside in one chief? The answer is no, governance is a shared responsibility of all, though it hovers around those entrusted to carry out the day-to-day functions and mandates of its people in order to discharge justice. However, there are no women amongst this group; women are mainly treated as passive, receptive, vulnerable and as reproducers. They are therefore not strong enough to face the challenges of the time. The Igbo Marxists adopted the strategy of exclusionism and of power to dominate, possess and penetrate women in order to keep the wheels of human procreation continuously spinning. The effects of domination associated with this power would arise not from appropriation and deployment by a subject, but from manoeuvres, tactics, techniques and functioning (Smart, 2002). I will like to talk about other main issues surrounding the subject.

This article however, will tackle some of the resilient and seemingly intractable issues in the traditional African marriage customs, and the influence exerted by the Western culture. In adapting a Marxist approach, I summarize how I believe Marxist's thought in Igbo tradition has developed during the period 1408-2008 and where it might go in the future. First, I summarize the evolution of coming of the Western society from the $15^{\text {th }}$ century upwards, focusing on liberal, radical, and Marxist-socialist capitalism. Next, I summarize the conception of marriage in Igbo land, the meaning and how it was carried out, taking a narrative approach, analysing the philosophical factor underpinning the custom. Third, I will critique with comparison the almighty bride-price concept and the Western cultural system. The last part will conclude that the bride-price had some significance both in the African and the Western context.

\subsection{Research Questions}

Based on the main research objectives and the theoretical underpinnings of the traditional marriage concepts in Igbo land and the entrant of the Western society, this study specifically seeks to answer the following research questions.

1) To what extent has pre-existing Igbo traditional marriage conditions been affected by the coming of the Western civilization?

2) To what extent does interrelatedness of cultures affect the institution of 
marriage in Igbo land?

3) To what extent does movement of people across cultures affect belief systems and marriage acceptability in Igbo land?

\section{Methodology}

This article is a qualitative research study and our approach for data collection is based on interview and online research of the tradition and culture of the Igbos dating back to $1400 \mathrm{AD}$. The use of online is necessitated by the nature of the question. Initially, literature search was conducted on various journals and books in an attempt to gain an overview of the issues of discourse associated with the Igbos' traditions and culture generally. Following from the above, a qualitative survey, involving two traditional indigenes of the Igbo descent was also undertaken in order to gather further context rich opinions, perceptions and views, based on individual knowledge, history and experience in relation to the subject. The survey was conducted in an atmosphere of openness; it included an open-minded session on how the traditional and cultural oriented marriages have shifted, how the traditions were observed and conducted before, and what is obtainable at the moment.

The paper also made use of researcher's personal experience and understanding of the culture and tradition of the Igbo people. Developing from the above, the researcher who is himself an insider of the culture and tradition of the Igbos draws upon both the literature and the experiences to develop an essay approach with a different style of genre, the Marxist style. Reflecting on Marxist approach and the interpretation of Igbo cultural marriage alongside the Western tradition of marriage on itself, the author illustrates his comments with some idiomatic expressions which littered all over the text as well as comments from references to Ezeokeke, Afikpo, Shaw, Anderson, Atado, Bruder, Nduka \& Ozioma, Adrian, Parekh, and Okeke to mention a few.

Bruder, (2008), begins by tracing the origin of the Igbo people as having migrated from the Jewish kingdom and are the descendants of Eri, the fifth son of Gad. Gad was one of the sons of Jacob, and Jacob the son of Abraham (Genesis 46: 15-18, \& Numbers 26: 16-18). Igbos have also been described as one of the most influential tribes in Nigeria known for their resilience, business acumen and hardworking characteristics, intelligence, enterprising and entrepreneurial spirit. Ezeokeke, (2018); Afigbo, (1981; 2011); Shaw, (1970), in their profiling of the arrival of the West into the shores of the Igboland provides that the Portuguese were the first to arrive in Igboland in the middle of fifteenth century. This was followed by the Dutch and the British in the seventeenth and eighteenth century respectively. What were they actually looking for out of their own shore? Could it be the result of cold and hunger? Africans were living in perfect peace at this time, proving policies and laws guiding their natural existence, marrying and giving in marriages until the arrival of these aliens. These foreigners purposely came to Igbo land in search of slaves, gold and copper. When the slavery 
was abolished in 1807, they diverted their mission economically on raw materials such as palm produce, elephant tusks, and timber. At this point, they appeared more aggressively oppressive in dealing with Africans who have now began to experience intimidation, wars and confrontations from the Europeans. As Foucault puts it; "concept forms human beings" thus the arrival and oppressive behaviour of the foreigners began to produce a new form of reasoning amongst the Igbos. Taking a look on the mission of the church in Africa, Adrian Hasting profiles the present ecclesiastical instance on the observance of canonical form in Africa which he says betrays the fundamental theology of marriage where the sacrament of matrimony is the sanctification of a natural relationship, made effective by the people themselves and not by any sacred minister (Hastings, (1995). Lamenting on this, Atado (1988) comments on the general possibility of profiling the West as having deprived the Igbos and indeed Africans in general the reception and good nature of the customary marriage as a result of the so-called regular union arising from Sacramento's Western Church wedding. On his part, Parekh (2000) insists that by mixing different cultures which resulted in marriage of convenience brought about by the coming of the West, the very core values of traditional marriage concept appeared to have been diluted. Thus, the struggle for recognition and cultural supremacy which went beyond the traditional plea for tolerance, thereby conceding the validity of society's disapproval and relying on its self-restraint (Parekh, 2000). Finally, the issue of bride price in traditional Igbo culture entails the exchange of money from groom to bride's family specifically, as complex and holistic. Thus, signifying the acquisition of the rights by the groom, of the bride's labour and reproductive ability (Anderson, 2007).

\subsection{Marxist Approach}

The first Igbo contact with the Europeans was in the middle of the fifteenth century with the arrival of the Portuguese. This was followed by the Dutch and the British in the seventeenth and eighteenth century respectively (Ezeokeke, 2018; Afigbo, 1981; 2011; Shaw, 1970). These Europeans came to Igbo land in search of slaves to buy. The abolition of slavery in 1807 ushered in a new wave of trade epoch. The European now shifted interest economically on raw materials, for example, palm produce, elephant tusks, and timber. Standpoint epistemology deals with the way individuals experience something and Africans have experienced intimidation, wars and oppressive confrontations from the West. Firstly, from the Arabs, and secondly from the Europeans, thus were forced to give Europeans' access to the hinterland. Foucault (1972) expressed that 'Concepts' form human beings, thus the arrival of Europeans began gradually to produce a new form of reasoning among the Igbos.

The traditional Igbo society believes in a strong family cohesion with power relation dominated by male. The people thrive on the notion of patriarchies which recognises male gender through paternal power (Nduka \& Ozioma, 2019), 
enabling them to hold more powers and privileges in the society. Traditionally, marriage among the Igbos transcends the notion of marriage as a bilateral contract or a "contract of convenience" seen as a covenant between two Umunnas (extended families) concretised in the spouses and binding existential. Neither the man nor the woman may derogate from or abrogate the sealed covenant without the knowledge of the two clans. The philosophy underlying this legal bond is "I am because we are, and since we are, therefore I am" It is a communal faith in equitable and just relationship between two people representing two autonomous clans. The underlying philosophical principle in the circumstance was to seal permanently an accord and war treaty between the two villages which will usher in peace, love and prosperity.

Through customary marriage, many relationships arise: economically and politically. It enhances trading and nullifies inter and intra-village disputes. Legally, a person's judicial rights are protected by the mother's agnates, if he is convicted of sorcery, then they will shelter him. There are two Igbo proverbs in support of this; "Woman is used to clear and maintain the passage of communication in foreign land" Another says, "The part of marriage is the part that leads to the stream and is always open". Stream is used here as a source of life, which may not shut her doors to the people she serves. These proverbs epitomise the human relationship initiated by marriage alliance. Through marriage, healthy relationships are established between the villagers, people regard each other as "brothers" and "sisters" and children from the marriage know they have a second home outside of their own homes.

\subsection{The Concept of Marriage in Igbo Land}

A marriage in Igbo tradition involves a whole series of prestation ("Prestation" is defined in the Oxford English Dictionary as "the act of paying, in money or service, what is due by law or custom") from the husband and his kin to the wife's kin. The Igbos would want to avoid the impression that the marital contract is in fact a sale or transaction. Hence the Igbo adage, “ $A$ man's debt to his in-laws can never be fully repaid". Thus, means that when we marry a wife, we must go on paying until we die. This however, justifies mutual interests between the in-laws and of course, gave the father in-law a slight edge over his son in-law. In the Western tradition, such act of service and mutual involvement does not take place. In fact, the closest one gets is the custom of giving the ring which was adopted from the Romans as a pledge to marry, which, also stood for marital contract among the Germans. The Franks followed the same procedure and bridegroom paid the wittum: (a wittum was a sum of money paid in compensation which indicated that somebody was protected). It became customary at this time (1563), that objects and practices such as the arrha (money), the ring, the bride-price, the veiling derived from Germanic, Frankish, Celtic, Longobardic, and Gothic tribes were thus incorporated into the custom of the societies (Atado 1988). 
In Igbo custom, the whole process of settlement is regulated; as the Igbos say, by the philosophy of the dog, "If I fall down for you and you fall down for me, it is a play". In other words, the settlement of bride-price is pervaded by humorous spirit and it involves no harshness or cantankerous bargaining of any kind. In other words, it is neither transactional, nor sales of any sorts. The ceremonies accompanying the payment of bride-price, though hugely diverse, elucidate the covenantal and religious ramifications of settlement. Unfortunately, the Igbo tradition appears not to give credence to man knelling before the girl lady to make propositions for marriage as it pertains to the modern kind of Western styled proposal where the bridegroom gets down on one knee to make propositions to his groom.

\subsection{Getting Married in Igbo Land}

In traditional African culture especially the Igbos, when a boy thinks he ought to get married, he first informs his father of his wish and intention. Then his situation is vetted to make sure he can support a wife and possibly a family (Okeke 1986). The family now starts to look for a wife for him. "The African marries and then falls in love", so the saying goes. The young man who now wants to marry may or may not have a say in the choice of his partner to be. The same also applies to the girl. In Igbo culture, it is not a matter for two individuals to decide; you get married to, or you marry into a family chosen for you. Usually, the families undergo a vetting order for any criminal records or any deadly diseases. This aspect of the fundamentals of marriage (vetting) predates making any marriage intentions known to the other family and must be carried out to the highest order before the marriage takes place.

\subsection{The Influence of the "Western Society"}

In Western culture, marriages may be contracted without the knowledge of the two families and parental consent sometime is not sought. " $A$ boy meets a girl and they fall in love and later decide to marry and agree on it". They then inform their parents about it and all is arranged (Okeke 1986). The underlying philosophical and cultural assumption in this instance could be based on Judeo-Christian religious backgrounds and Greco-Roman law. Right from the time of the decretals to the Council of Trent, legislation had supported the validity of marriage contracted without parental consent. The capacity of persons is determined by the natural law, the State and the customary law for the un-baptised, and by the canonical law for those who are baptised or received into the church. In 1198 Pope Innocent 111 declared that only the consent of the contracting parties was necessary for a valid marriage. Thus, has since become part of the cultural norms of the West (Atado, 1988) and has remained so.

Consequently therefore, an individual in the Western society is free to choose his or her own marital partner; (a practice that is abhorred in Igbo traditions and culture) parents and kinsmen were not normally involved and therefore neither 
made the choice nor entered into marriage negotiations on behalf of the partners. Young people reaching the legal age in the West enjoyed a great deal of freedom in the choice of marriage partners based on the aforementioned cultural, religious or canonical, state and customary laws of the society.

However, in the recent time, a new wave of marriage practice has begun to emerge among many educated Africans. This is marriage without family consent, contracted as a result of direct influence of the 'Christian - Western' culture brought about by well-travelled and educated Africans, who see traditional practices as inhibiting and narrow-minded. These new educated African elites returned home imbued with nationalism and reformative mind sets, believing to make vital cultural contributions towards influencing traditional institution of marriage in Africa. Their new adopted way of life being responsible, stood between two traditional and cultural values. For example, in a study conducted by Nwoko, "The Changing Nature and Patterns of Traditional Marriage Practices among the Owerre-Igbo, a Subgroup of the Igbo of Southeast Nigeria" which examines the acculturation that shapes the contemporary social construct of marriage in Igboland and in particular the Owerri-Igbo social enclave, the study found the following three phenomena to be responsible: 1) the extensive contacts which the Owerre-Igbo have had with other ethnic groups, 2) the influence of Christianity and Western education, and 3) occupational influence (Nwoko, 2020).

Although, some authors also see the traditional marriage practices as repugnant: they believe that "it is helping to refine some of the obnoxious beliefs and practices of Igbo race" (Okeke, Ibenwa, \& Okeke, 2017). Nonetheless, their ideas did not go far enough in changing the orthodoxy and tradition of marriage in certain parts of Africa, especially among the Igbo race because of lack of mutual-cultural recognition. Mutual-cultural recognition acknowledges the common benefits, interests and goals of a particular race (Berger et al., 2008). In this context, the Igbo race. Conversely, the culture of the Igbos favours patriarchal system thus, the general believes that traditional orthodoxy in marriage rights within the Igbo race or indeed within Africa, needs to be maintained, sustained and celebrated without undue alteration irrespective of our Western education. On the other hand, while acknowledging the agency of Western cultural influence by well-educated Africans, I argue that many Africans' would-be spouses/couples have appeared to shape their marriage rights towards, rather than away from traditional and cultural norms, actually embraced the concept and the rituals, believing the significance to be a worthwhile cultural identity.

\section{Critical Analysis and Result}

\subsection{Critical Analysis of Igbo Traditional Marriage and Western Styled Wedding}

The significance of bride-price in marriages within the Igbo land can be compared with the wedding in early England: where the bridegroom first swore ac- 
cording to God's right and circular law, waging (pledging himself) to the girl's for speakers, to have her in such a way as he should hold by God's right as his wife, and his kinsmen would stand pledge for him. In such circumstance, the price of "up-fostering" the bride was interpreted as compensation to the bride's immediate family. Similarly, among the Igbos, the bride-price is conceived as a sign of appreciation and gratitude to the bride's immediate family for rearing her: it is therefore a pledge of fidelity and commitment made by the groom and his people to the bride and her kin. This pledge is water tight and must be seen by all to be so. Though, it must go without saying that the bride-price alone does not confer to the groom, the onus and powers of husband-ship until traditional wine carrying otherwise called "Igba-nkwu" has taken place.

Conceivably, the payment of bride-price in Igbo land guarantees the legal transfer of the woman from the patria potestas to the authority of her husband and his kin. In the early English marriage, this process was called "the transfer of the woman's mund from the father to the husband. Furthermore, bride-price specifies the right and corresponding duties of a husband and wife, and of the parent vis-à-vis their children.” Meek (1937) aptly enunciates the legal bond that arises from the payment of bride-price: "It further guarantees that the husband shall have the custody of any children born; for in the absence of bride-price a woman's children are claimed by her family (Custody of the children is decided not solely in terms of physiological or biological paternity). Traditionally, bride-price guarantees that the husband shall have the continuous services of a wife for himself and of a mother for his children, and that a wife and the offspring produced shall have a permanent home, and be supported by her husband. It thus prevents wife from leaving her husband for some trivial cause(s)," as it is commonly the case in the Western civilization, where a minor economic problem may lead to dissolution of a marriage through devoice and children (if any) from the marriage becomes subject to court decision. Psychologically, the bride price in Igbo land is naturally symbolic in the sense that it adds value, honour and dignity to the bride. This is even so, since any marriage contracted without the bride price for any reason whatsoever in Igboland is considered incomplete in the first place. Culturally and unfortunately, the woman involved in such marriage contract is believed to be given out free of charge, and therefore, is considered not fully married. More so, the woman in question will always feel inferior and less valued within the family where she was married into and even amongst her peers. This act, obviously affects her full integration into her husband's wider family. Conversely, such practice however, is not common or not obtainable in the western socio-cultural domain. The Western marriage culture did not see any issue attached to the payment of bride price, hence, a woman and a man on their own accord can cohabit with or without the consent of their parents and continue procreation if they so wish. Be it as it may conform to their life style and culture, such practice would be a taboo in Igbo land wherefore children are created without proper marriage rights, such children created in 
that manner would be called bastards and may not have the full legal right of possession in the family properties.

Nevertheless, due to colonisation and the impact of Western socio-cultural activities, traditional method of marrying a wife in Igboland have appeared to unavoidably been corrupted and disrupted. The traditional Igbo marriage practice was seen to be decreasing at an increasing rate and gradually being replaced with a scandalous mercantile procedure. In effect, the institution of bride-price has become commercialised in Igbo society, not sorely on the bride price but also on the entire ceremonies surrounding marriages in Igbo society. Not surprisingly, with the growth of the economy of nations, the amount of bride-price began to escalate, and thus precipitated many distressing and lamentable problems in the society. The question now is; can we reject the African heritage in favour of the alien values and cultures? The answer is neither to reject the alien values and cultures nor to substitute with African heritage in all spheres of people's lives, but an incorporation and development of the Igbo traditions, values and culture in philosophy, theology and Christianity as Rev. Atado (1988) has observed which might improve and strengthen the institution of marriage in Igbo land.

\subsection{Summary of Research Findings}

Whereas it is the right of individuals to contract marriage without the consent of their parents in the Western culture, the Igbo society abhors this tradition; in fact, in Igboland and more so in African context, marriage is seen as a union of two different families.

Notably, among Igbos, the bride-price is conceived as a sign of appreciation and gratitude to the bride's immediate family for rearing her: the concept which is not obtainable in the Western society marriage rights.

Payment of bride-price in Igbo land guarantees the legal transfer of the woman from the patria potestas to the authority of her husband and his kin, again this aspect of tradition does not exist in the Western society. The legal transfer of the woman can only be witnessed either in the case of Court marriages or the Church Wedding.

whereas it is right to cohabit and procreate children in the Western marriage, it is rather a taboo to create children without proper marriage rights in Igbo tradition and such children created in that manner would be called bastards and may not have the full legal right of possession in the family properties.

$>$ Finally, due to the influence of the Western culture in Igbo society, the institution of bride-price has become commercialised, not sorely on the bride price but also on the entire ceremonies surrounding marriages in Igbo society thus, the amount of marrying a girl has escalated astronomically.

\section{Conclusion}

In conclusion, therefore, the researcher re-visits the fundamental issues of Afri- 
can (the Igbo) traditional marriage customs and the influence of the western styled marriages. Marriage and Family, according to NCTC (2010), are the study of the problems of mate selection, courtship, conflict resolution, childrearing, common relationship issues, marriage adjustment, divorce and remarriage. Although, this definition is apparent in both cultures, it is more visible and adaptive in African Igbo traditional and cultural setting than it is in western culture.

This genre paper examined the traditional culture and the invasion of the Western liberal practices (Okeke 1986). "The researcher adopted a Marxist perspective in this genre paper" for two reasons; firstly, in order to explain or expose the insanity of the traditional and cultural contamination that characterized the early entrants of the West into the traditional homeland of the Igbos. Secondly, Marxist perspective was particularly helpful, since it enabled the researcher to critique both the custom and tradition of marriage that had existed in Igbo land prior, and the influence of the West through the Church and Canonical laws. By merit, meaning, belief, adoption and application, marriage in African setting (i.e., the Igbos) is radically different from marriage setting in the Western world (the Europeans and Americans). It is however, true to say that African tradition and culture brings many rich values into a marriage but it can also bring its own crop of problems with it.

However, in conclusion therefore, the researcher is of the opinion that religious beliefs, education, and western civilization have independent association with Igbo traditional marriage concepts; adequate intervention is needed therefore, to address the social and culturally-laden norms that vary amongst the traditional Igbo marriage and custom which was brought about by Western culture.

\section{Conflicts of Interest}

The author declares no conflicts of interest regarding the publication of this paper.

\section{References}

Afigbo, A. E. (1981). Ropes of Sand: Studies in Igbo History and Culture. Published for University Press.

Afigbo, A. E. (2011). Prolegomena to the Study of the Culture History of the Igbo-Speaking Peoples of Nigeria. In B. K. Swartz, \& R. E. Dumett (Eds.), West African Culture Dynamics (pp. 305-326). De Gruyter Mouton. https://doi.org/10.1515/9783110800685.305

Alewo A. J. M., \& Olong, M. A. (2012). Cultural Practices and Traditional Beliefs as Impediments to the Enjoyment of Women's Rights in Nigeria. International Law Research, 1, 134-143. https://doi.org/10.5539/ilr.v1n1p134

Anderson, S. (2007). The Economics of Dowry and Brideprice. Journal of Economic Perspectives, 21, 151-174. https://doi.org/10.1257/jep.21.4.151

Atado, C. J. (1988). African Marriage Customs and Church Law: A Case Study of the Igbo People. The Modern Printers Ltd.

Berger, M. S., Van der Plas, E., Huygens, C., Akrimi, N., \& Schneider, C. (2008). Bridge 
the Gap, or Mind the Gap? Culture in Western-Arab Relations (No. 15, pp. 1-54). Netherlands Institute of International Relations "Clingendael".

Bruder, E. (Ed.) (2008). The Black Jews of Africa: History, Religion, Identity (p. 143). Oxford University Press. https://doi.org/10.1093/acprof:oso/9780195333565.001.0001

Emecheta, B. (2011). The Joys of Motherhood. WW Norton \& Company.

Eniola, B. O., \& Aremo, J. I. (2020). Bride Price and Sexual and Reproductive Rights of Women: A Case Study of South Africa and Nigeria. Journal of Law, Policy and Globalization, 96, 26-33.

Ezeokeke, E. C. (2018). The Identity of the Catholic Church in Igboland, Nigeria.

Foucault, M. (1972). The Archaeology of Knowledge. Translated from the French by A. M. Sheridan Smith, Pantheon Books.

Hastings, A. (1995). The Church in Africa, 1450-1950. Clarendon Press. https://doi.org/10.1093/0198263996.001.0001

Meek, C.K. (1937). Law and Authority in a Nigerian Tribe. Oxford University Press.

NCTC (North Central Texas College) (2010). SOCI 2301 Marriage and Family Relationships: North Central Texas College.

Nduka, U. and Ozioma, N. (2019) Chinua Achebe's Things Fall Apart and the Role of Women in Igbo Traditional Religious Culture. Open Journal of Social Sciences, 7, 272-289. https://doi.org/10.4236/jss.2019.712020

Nwoko, K. C. (2020). The Changing Nature and Patterns of Traditional Marriage Practices among the Owerre-Igbo, a Subgroup of the Igbo of Southeast Nigeria. Journal of Historical Sociology, 33, 681-692. https://doi.org/10.1111/johs.12295

Oduah, C. (2013). Nigeria’s Igbo Jews: “Lost Tribe” of Israel? CNN. http://www.cnn.com/2013/02/01/world/africa/nigeria-jews-igbo/

Okeke, C. O., Ibenwa, C. N., \& Okeke, G. T. (2017). Conflicts between African Traditional Religion and Christianity in Eastern Nigeria: The Igbo Example. Sage Open, 7, Article ID: 2158244017709322 . https://doi.org/10.1177/2158244017709322

Okeke, K. (1986). “Made for Love”: Marriage as It Was Meant to. Lion Publishing plc.

Parekh, C. B. (2000). Rethinking Multiculturalism: Cultural Diversity and Political Theory. MacMillan Press Ltd.

Ryznar, M. (2010). All's Fair in Love and War: But What about in Divorce-The Fairness of Property Division in American and English Big Money Divorce Cases. North Dakota Law Review, 86, 115-148.

Shaw, T. (1970). An Account of Archaeological Discoveries in Eastern Nigeria. Faber and Faber Limited.

Smart, B. (2002) Michel Foucault (Revised ed.). Routledge. 